\title{
ANALISIS KELAYAKAN STRUKTUR BANGUNAN PUBLIK 5 LANTAI DI KOTA JAKARTA
}

\author{
Agustinus Putra N.S., Cindrawaty Lesmana \\ Program Studi Teknik Sipil, Universitas Kristen Maranatha \\ Jalan Prof. drg. Surya Sumantri, MPH, No. 65, Bandung, 40164
}

\begin{abstract}
ABSTRAK
Pertumbuhan ekonomi yang sangat pesat menjadi alasan banyaknya pembangunan gedung di Indonesia. Indonesia merupakan negara rawan gempa bumi karena dilalui oleh jalur pertemuan 3 lempeng tektonik, yaitu lempeng Indo-Australia, lempeng Eurasia, dan lempeng Pasifik, tentunya teknologi dalam menganalisis suatu struktur bangunan telah berkembang dengan memperhatikan risiko terhadap dampak dari bencana. Analisis kelayakan struktur diperlukan untuk meninjau desain awal terhadap kondisi yang diinginkan pada perencanaan dengan melakukan beberapa identifikasi yang sesuai dengan ketentuan standar yang telah ditentukan. Tujuan penelitian adalah menganalisis kelayakan struktur bangunan eksisting dengan meninjau tingkat kerusakan dan simpangan yang terjadi. Analisis kelayakan struktur untuk pemodelan struktur dilakukan berdasarkan investigasi visual, denah arsitektur, data hasil pengujian kuat tekan beton, dan data hasil pengujian tulangan beton. Hasil pengamatan visual adalah terdapat retak pada pelat beton dan balok beton.. Hasil analisis dinamik respon spektrum menunjukkan bahwa kontrol simpangan antar lantai pada arah- $\mathrm{x}$ dan arah-y tidak memenuhi persyaratan. Hasil analisis pushover menunjukkan bahwa tingkat kerusakan yang terjadi pada bangunan publik 5 lantai sudah mencapai pada tingkat kerusakan yang signifikan dimana struktur sudah tidak mampu menahan gaya geser dan terjadi degradasi kekuatan struktur yang besar.
\end{abstract}

Kata kunci: bangunan publik, kelayakan struktur, investigasi visual, pengujian beton, analisis respon spektrum dinamik, analisis pushover.

\begin{abstract}
Rapid economic growth is the reason for the many building developments in Indonesia. Indonesia is a country prone to earthquakes because it is traversed by a meeting path of 3 tectonic plates, namely the Indo-Australian plate, the Eurasian plate, and the Pacific plate, of course technology in analyzing a building structure has developed with regard to risks to the impact of disasters. Structural feasibility analysis is needed to review the initial design of the desired conditions in the planning by carrying out several identifications in accordance with the provisions of the standards that have been determined. The purpose of the study was to analyze the feasibility of the existing building structure by reviewing the level of damage and deviation that occurred. Structural feasibility analysis for structural modeling is based on visual investigations, architectural plans, concrete compressive strength testing data, and concrete reinforcement test data. The result of visual observation is that there are cracks on the concrete plates and concrete beams. The results of the dynamic response of the spectrum response indicate that the control of intersections between floors in the $x$-direction and $y$-direction do not meet the requirements. The results of the pushover analysis show that the level of damage that occurs in 5-story public buildings has reached a significant level of damage where the structure is not able to withstand shear forces and large structural degradation occurs.
\end{abstract}

Keywords: public buildings, structural feasibility, visual investigation, concrete testing, dynamic spectrum response analysis, pushover analysis 


\section{PENDAHULUAN}

\subsection{Latar Belakang}

Pembangunan gedung-gedung bertingkat di Indonesia semakin meningkat dari tahun ke tahun. Dalam merencanakan bangunan sangat diperlukan analisis yang optimum terhadap kekuatan dan kelayakan suatu struktur demi kepentingan keselamatan pengguna bangunan. Analisis kelayakan struktur dilakukan untuk meninjau desain awal terhadap kondisi yang diinginkan pada perencanaan dengan melakukan berberapa identifikasi yang sesuai dengan ketentuan standar yang telah ditentukan (Williams, 2007).

Metode untuk mengevaluasi kelayakan struktur bangunan dengan melakukan jenisjenis tindakan dan pengujian yaitu pengamatan visual, pemetaan struktur, dan pengambilan benda uji inti beton (core drill) (Nobel, 2016). Analisis respon dinamik untuk perancangan struktur tahan gempa dilakukan jika diperlukan evaluasi yang lebih akurat terhadap gaya-gaya gempa yang bekerja pada struktur, serta untuk mengetahui perilaku dari struktur akibat pengaruh gempa (Purnomo E., 2014). Analisis pushover dilakukan dengan memberikan peningkatan beban lebih lanjut, hingga mengalami perubahan bentuk pasca elastik yang besar sampai mencapai kondisi plastik (Pranata, Y.A., 2006).

Tujuan penelitian adalah menganalisis kelayakan struktur bangunan eksisting dengan meninjau tingkat kerusakan dan simpangan yang terjadi dengan analisis respon dinamik dan analisis beban dorong (pushover). Penelitian dilakukan pada salah satu bangunan publik 5 lantai di Kota Jakarta. Metode analisis respon dinamik dan pushover analysis dengan bantuan perangkat lunak Extended Three Dimension Analysis of Building System (ETABS).

1. Analisis dilakukan sebatas mengevaluasi kelayakan struktur dengan melihat tingkat kerusakan struktur dan simpangan pada bangunan.

2. Struktur gedung yang ditinjau adalah dan berfungsi sebagai gedung arsip;

3. Bangunan berlokasi di Kota Jakarta, sehingga perhitungan beban gempa rencana berdasarkan peta Gempa SNI 1726-2012 dengan asumsi tanah sedang;

4. Data yang diperoleh dari perusahaan yaitu gambar arsitektur, data struktur, dan data hasil pengujian beton;

5. Mutu beton berdasarkan hasil pengujian inti beton (core drill);

6. Mutu baja tulangan ulir $\left(f_{y}=390 \mathrm{MPa}\right)$ dan mutu baja tulangan polos $\left(f_{y s}=\right.$ $240 \mathrm{MPa})$; 
7. Hanya dan tidak sampai retrofit bangunan;

8. Tidak dilakukan perencanaan anggaran biaya terhadap objek penelitian;

9. Tidak dilakukan detailing elemen komponen struktur;

10. Meninjau bagian upper structure, sehingga pondasi diasumsikan kuat;

11. Peraturan yang digunakan untuk menganalisis beban gempa adalah SNI 1726:2012, peraturan pembebanan mengacu pada SNI 1727:2013, peraturan beton bertulang mengacu pada SNI 2847:2013.

\section{TINJAUAN LITERATUR}

\subsection{Kelayakan Struktur Bangunan}

Kelayakan struktur bangunan sangat diperlukan pada bangunan eksisting. Metode yang dapat dilakukan untuk meninjau kinerja gedung untuk kelayakan strukturnya dapat dilakukan dengan beberapa fase yaitu:

a) Fase Screening

Fase Screening merupakan bentuk evaluasi pada saat gedung terkena peristiwa gempa., dengan melakukan pengamatan visual atau pengumpulan data.

b) Fase Evaluasi

Fase Evaluasi merupakan fase dengan melakukan analisis terhadap gedung yang bersangkutan dengan melihat tingkat kinerja bangunan (level of perfomance) seperti yang diinginkan FEMA 310.

Metode lainnya yang dapat dilakukan untuk melihat kelayakan struktur bangunan adalah melakukan beberapa pengujian terhadap elemen struktur gedung. Pengujian yang dilakukan untuk melihat kelayakan strukturnya sebagai berikut:

a) Pengujian Kuat Tekan Beton Inti Pengujian kuat tekan beton inti adalah pengujian yang bersifat semi destructive dengan maksud untuk memperkirakan nilai kuat tekan beton. Pelaksanaan pengujian ini dilakukan di lapangan dan laboratorium. Nilai kuat tekan beton yang didapat dari hasil pengujian digunakan untuk analisis gedung yang bersangkutan.

b) Pemeriksaan Konfigurasi Tulangan

Pemeriksaan ini bertujuan untuk mengetahui kondisi tulangan terpasang. Alat yang digunakan untuk pemeriksaan ini berupa R-bar meter. Alat ini dapat memperkirakan tebal selimut beton, jumlah tulangan dan jarak tulangan yang terpasang pada suatu komponen struktur. 


\subsection{Analisis Bangunan Tahan Gempa}

Analisis gempa atau seismik adalah analisis struktur dan perhitungan respon dari sebuah bangunan struktur untuk gempa bumi. Ada beberapa metode untuk menganalisis bangunan tahan gempa. Metode analisis bangunan tahan gempa yang dimaksud adalah elastis (linear) dan inelastis (nonlinear). Metode analisis elastis (linear) yaitu analisis statik ekivalen dan analisis dinamik respon spektrum, sedangkan metode analisis inelastis meliputi analisis statik beban dorong (static nonliniear/pushover analysis) dan analisis riwayat waktu (inelastic dynamic time history analysis).

\subsubsection{Analisis Dinamik Respon Spektrum}

Analisis dinamik adalah analisis struktur dimana pembagian gaya geser gempa di seluruh tingkat didapat dengan memperhitungkan pengaruh dinamik gerakan tanah struktur. Analisis respon spektrum adalah analisis dinamik dimana total respon didapat melalui superposisi dari masing-masing ragam getar. Analisis respon spektrum dilakukan dengan input dari grafik spektrum respon gempa yang nilai ordinatnya dikalikan faktor skala, nilai faktor skala dihitung menggunakan Persamaan 2.1

$$
f=\frac{\boldsymbol{w}}{\mathbf{n}}
$$

Keterangan:

$\mathrm{f} \quad$ Faktor skala perbesaran

$I_{e}=$ Faktor keutamaan gempa

$\mathrm{R}=$ Koefisien modifikasi respons

$\mathrm{g}=$ Percepatan gravitasi bumi yaitu $\mathrm{g}=9,81 \mathrm{~m} /$ detik $^{2}$

Hasil analisis dinamik respon spektrum setelah mengalami faktor perbesaran skala, selanjutnya kontrol nilai akhir respon spektrum (Gaya Geser/Base Shear) dan kontrol hasil simpangan yang terjadi pada bangunan.

1) Kontrol Nilai Akhir Respon Spektrum (Gaya Geser/Base Shear)

Berdasarkan SNI 1726:2012 pasal 7.9.4, nilai akhir $V_{\text {dinamik }}$ harus lebih besar sama dengan $85 \% V_{\text {statik. }}$. Persyaratan tersebut dinyatakan dengan Persamaan 2.2.

$V_{\text {dinamik }} \geq 0,85 \mathrm{~V}_{\text {statik }}$

2) Simpangan Antar Lantai 
Penentuan simpangan antar lantai tingkat $(\Delta)$ dihitung sebagai perbedaan defleksi pada pusat massa di tingkat teratas dan terbawah yang ditinjau berdasarkan Persamaan 2.3.

$\delta_{x}=\left[\left(C_{d} x \delta_{x e}\right) / I_{e}\right]$

Keterangan:

$C_{d}=$ Faktor amplifikasi defleksi

$\delta_{x e}=$ Defleksi pada lokasi yang diisyaratkan

$I_{e} \quad=$ Faktor keutamaan gempa yang ditentukan

Simpangan antar lantai tingkat desain tidak boleh melebihi simpangan antar lantai tingkat izin, nilai simpangan antar lantai tingkat izin ditunjukkan pada Persamaan 2.4.

$\Delta_{\mathrm{ijin}} \quad=0,020 \mathrm{hsx} / \mathrm{\rho}$

Keterangan:

hsx $=$ tingkat dibawah tingkat $\mathrm{x}$

$\rho=$ faktor redundasi

Simpangan antar lantai yang diizinkan adalah $\Delta a=0,020 \mathrm{hsx}$. Berdasarkan SNI pasal 7.12.1.1 untuk struktur rangka pemikul momen khusus $\mathrm{KDS}=\mathrm{D}$, maka nilai $\Delta a$ harus dibagi dengan $\rho=1,3$.

\subsubsection{Analisis Pushover}

Analisis pushover adalah analisis beban dorong statik untuk mengetahui perilaku keruntuhan suatu bangunan gedung terhadap gempa. Analisis dilakukan dengan memberikan pola suatu beban lateral statik pada suatu struktur bangunan, kemudian secara bertahap ditingkatkan dengan faktor pengali sampai satu target perpindahan lateral dari suatu titik acuan tercapai. Tujuan analisis pushover adalah untuk memperkirakan gaya maksimum dan deformasi yang terjadi serta untuk memperoleh informasi bagian mana saja yang kritis. 
Tabel 2.1 Tingkat Kerusakan Struktur

\begin{tabular}{|c|c|l|}
\hline Keterangan & Simbol & \multicolumn{1}{|c|}{ Penjelasan } \\
\hline & B & $\begin{array}{l}\text { Menunjukan batas linear yang kemudian diikuti } \\
\text { terjadinya pelelehan pertama pada struktur }\end{array}$ \\
\hline & IO & $\begin{array}{l}\text { Terjadi kerusakan yang kecil atau tidak berarti pada } \\
\text { struktur, kekakuan struktur hampir sama pada saat } \\
\text { sebelum terjadi gempa }\end{array}$ \\
\hline & LS & $\begin{array}{l}\text { Terjadi kerusakan mulai dari kecil hingga sedang. } \\
\text { Kekakuan struktur berkurang tetapi masih mempunyai } \\
\text { ambang yang cukup besar terhadap keruntuhan }\end{array}$ \\
\hline & CP & $\begin{array}{l}\text { Terjadi kerusakan yang parah pada struktur sehingga } \\
\text { kekuatan dan kekakuannya berkurang banyak }\end{array}$ \\
\hline C & $\begin{array}{l}\text { Batas maksimum gaya geser yang mampu ditahan } \\
\text { gedung }\end{array}$ \\
\hline D & $\begin{array}{l}\text { Terjadinya degradasi kekuatan struktur yang besar, } \\
\text { sehingga kondisi struktur tidak stabil dan hampir } \\
\text { collapse }\end{array}$ \\
\hline & E & $\begin{array}{l}\text { Struktur sudah tidak mampu menahan gaya geser dan } \\
\text { hancur }\end{array}$ \\
\hline
\end{tabular}

Sumber: P.A. Budi, 2011

\section{A. Tingkat Kerusakan}

ATC-40 (1996) menjelaskan bahwa perilaku suatu struktur yang diukur dari tingkat taraf kerusakan struktural dan non struktural yang terjadi. Empat kerusakan utama pada taraf kerusakan struktural adalah sebagai berikut:

1) Immediate Occupancy: bila terjadi gempa, hanya sedikit kerusakan struktural yang terjadi, karakteristik dan kapasitas sistem penahan gaya vertikal dan lateral pada struktur masih sama dengan kondisi diman gempa belum terjadi, sehingga bangunan aman dan dapat dipakai.

2) Damage Control: pemodelan bangunan baru dengan beban gempa rencana dengan nilai beban gempa yang peluang dilampauinya dalam rentang masa layan gedung 50 tahun adalah $10 \%$.

3) Life Safety: bila terjadi gempa, mulai muncul kerusakan yang cukup signifikan pada struktur, akan tetapi struktur masih dapat menahan gempa. Komponenkomponen struktur utama tidak runtuh. Bangunan dapat dipakai kembali bilamana sudah dilakukan perbaikan, walaupun kerusakan yang terjadi masih seringkali membutuhkan biaya yang tidak sedikit. 
4) Limited Safety: kondisi bangunan tidak sebaik level life safety dan tidak seburuk level structural stability, termasuk ketika level life safety tidak efektif atau ketika hanya beberapa kerusakan struktur kritis yang dapat dikurangi.

5) Structural Stability: level ini merupakan batas dimana struktur sudah mengalami kerusakan yang parah. Terjadi kerusakan pada struktur dan nonstruktur. Struktur tidak lagi mampu menahan gaya lateral karena penurunan.

6) Not Considered: dalam kategori ini, struktur sudah dalam kondisi runtuh,

B. Sendi Plastis

Sendi plastis merupakan zona leleh pada elemen struktur yang akibat beban yang menyebabkan regangan menjadi besar (Douglas, K.T.,1995). Struktur Gedung apabila menerima beban gempa pada kondisi tertentu, maka akan terjadi sendi plastis pada gedung. Sendi plastis merupakan bentuk ketidakmampuan elemen struktur (balok dan kolom) menahan gaya dalam.

\section{Hinge properties balok}

Data hinge properties dimasukkan pada penampang daerah tumpuan balok yaitu lokasi dimana diharapkan terjadi. Masing-masing penampang balok dimodelkan dengan pilihan model momen M3, artinya sendi plastis hanya terjadi karena momen searah sumbu lokal 3. Posisi sumbu lokal balok struktur dapat dilihat pada Gambar 2.1 (a).

\section{Hinge Properties Kolom}

Data hinge properties kolom adalah model P-M2-M3. Model P-M2-M3 adalah sendi plastis terjadi dikarenakan adanya interaksi gaya aksial (P) dan momen (M) sumbu lokal 2 dan sumbu lokal 3, seperti yang terlihat pada Gambar 2.1 (b).

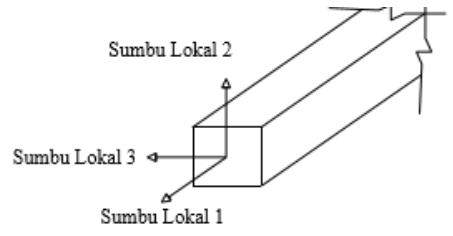

(a) Balok

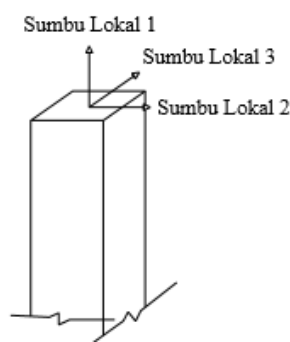

(b) Kolom

Gambar 2.1 Posisi Sumbu Lokal Elemen Struktur Sumber: Dewobroto, 2007 
3. Penentuan letak sendi plastis

Penentuan letak sendi plastis pada elemen struktur balok dan kolom terjadi sesuai yang diinginkan. Posisi 0 menyatakan posisi awal dari panjang bersih balok dan kolom, sedangkan posisi 1 menyatakan posisi akhir dari panjang bersih balok dan kolom.

\section{METODE PENELITIAN}

Penelitian dilakukan dengan survei bangunan untuk meninjau ulang seperti melakukan investigasi pada bangunan, pengukuran atau pengecekan dimensi balok induk, balok anak dan kolom, melihat posisi komponen struktur bangunan, serta peninjauan fungsi ruang pada bangunan publik 5 lantai (gedung X). Data yang terkumpul kemudian dibuat pemodelan struktur bangunan pada program dan dilakukan analisis untuk bangunan publik 5 lantai ini dengan metode respon dinamik dan pushover. Analisis yang telah dilakukan, kemudian dilakukan evaluasi kelayakan bangunan.

\subsection{Investigasi Bangunan}

Investigasi adalah penyelidikan dengan mencatat atau merekam fakta melakukan peninjauan, percobaan, dan sebagainya, dengan tujuan memperoleh jawaban pernyataan, penyelidikan (KBBI, 2015). Investigasi secara garis besar untuk memperkirakan adanya kerusakan atau tidak pada bangunan eksisting. Peninjauan pada bangunan publik 5 lantai dilakukan pada tanggal 19 Oktober 2016. Hasil observasi gedung X ditunjukkan pada Gambar 3.1. 


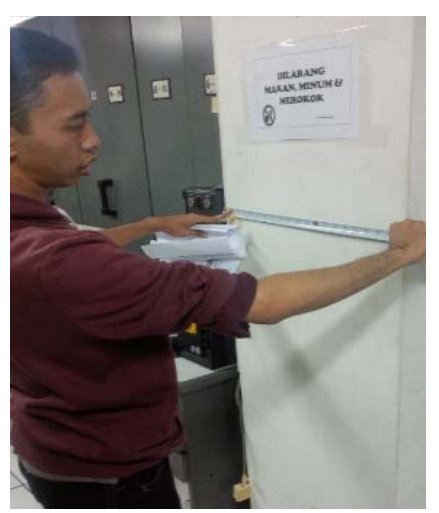

(a)

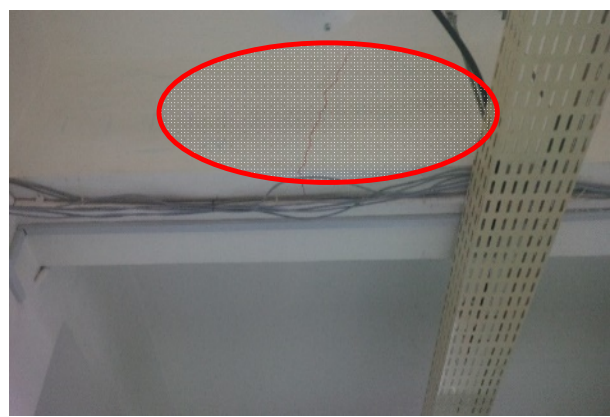

(c)

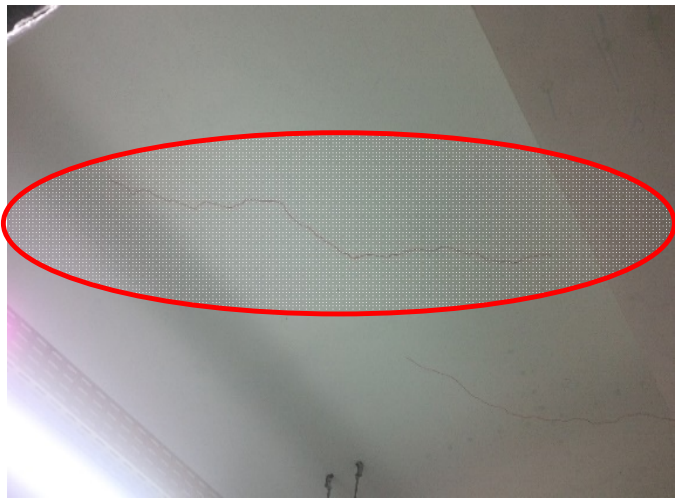

(b)

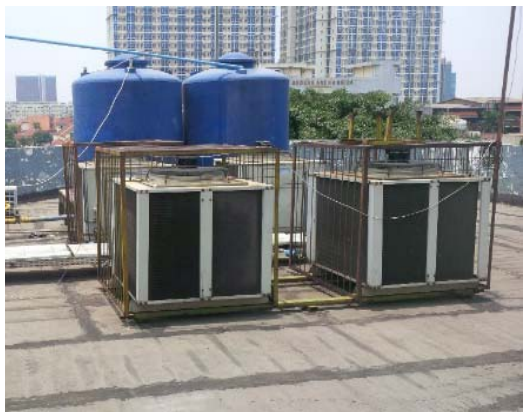

(d)

Gambar 3.1 (a) Pengukuran dimensi struktur kolom, (b) Retak pelat lantai 4, (c) Retak balok induk lantai 4, (d) Beban pada dak atap

\subsection{Hasil Pengujian}

Pengujian lapangan yang dilakukan adalah pengujian core drill yang dilakukan oleh Pusat Penelitian dan Pengembangan Permukiman (Puskim). Pengujian dilakukan pada semua elemen struktur beton bertulang bangunan eksisting yang ditinjau. Nilai kuat tekan mutu beton berdasarkan hasil pengujian core drill ditunjukkan pada Tabel 3.1. 
Tabel 3.1 Nilai Kuat Tekan Beton Inti

Untuk Setiap Komponen Struktur

\begin{tabular}{|c|c|c|c|c|c|}
\hline No & \multicolumn{2}{|c|}{$\begin{array}{l}\text { Komponen } \\
\text { Struktur }\end{array}$} & $\begin{array}{l}\text { Ukuran } \\
\text { (mm) }\end{array}$ & $\begin{array}{c}f_{c}^{\prime} \\
\left(\mathrm{N} / \mathrm{mm}^{2}\right)\end{array}$ & $\begin{array}{l}\text { Modulus Elastisitas } \\
\qquad\left(\mathrm{N} / \mathrm{mm}^{2}\right)\end{array}$ \\
\hline \multirow{5}{*}{1} & \multirow{5}{*}{ Kolom } & K1 & $520 \times 520$ & 13,01 & 16952,61 \\
\hline & & K2 & $520 \times 520$ & 13,03 & 16965,63 \\
\hline & & K3 & $520 \times 520$ & 14,74 & 18044,57 \\
\hline & & K4 & $520 \times 520$ & 11,07 & 15637,66 \\
\hline & & K5 & $520 \times 520$ & 14,72 & 18032,33 \\
\hline \multirow{5}{*}{2} & \multirow{5}{*}{ Balok } & B1 & $300 \times 500$ & 18,30 & 20105,89 \\
\hline & & B2 & $300 \times 500$ & 15,61 & 18569,46 \\
\hline & & B3 & $300 \times 500$ & 16,84 & 19287,19 \\
\hline & & B4 & $300 \times 500$ & 15,82 & 18693,95 \\
\hline & & $\mathrm{BA}$ & $200 \times 400$ & 14,52 & 17909,41 \\
\hline \multirow{4}{*}{3} & \multirow{4}{*}{ Pelat } & $\mathrm{A}$ & 112 & 27,20 & 24512,20 \\
\hline & & B & 112 & 28,21 & 24963,15 \\
\hline & & $\mathrm{C}$ & 112 & 24,61 & 23315,98 \\
\hline & & $\mathrm{D}$ & 112 & 18,04 & 19962,55 \\
\hline
\end{tabular}

\section{ANALISIS STRUKTUR DAN PEMBAHASAN}

\subsection{Analisis Dinamik Respon Spektrum}

Analisis respon spektrum adalah analisis dinamik dimana total respon didapat melalui superposisi dari masing-masing ragam getar. Analisis dinamik dilakukan dengan cara melakukan pemodelan struktur bangunan yang ditinjau dengan bantuan program Extended Three Dimension Analysis of Building System (ETABS). Hasil pemodelan struktur untuk analisis dinamik respon spektrum akan ditinjau dan disesuaikan dengan Standar Tata Cara Perencanaan Ketahanan Gempa 1726:2012.

\subsubsection{Partisipasi Ragam}

Analisis menentukan ragam getar alami untuk struktur harus menyertakan jumlah ragam yang cukup untuk mendapatkan partisipasi massa ragam paling sedikit $90 \%$ dari massa aktual dalam masing-masing arah horisontal ortogonal dari respons yang ditinjau oleh model. Hasil analisis partisipasi masa ragam yang diperoleh dari pemodelan struktur bangunan publik 5 lantai (gedung X) dapat dilihat pada Tabel 4.1 . 
Tabel 4.1 Participating Mass Ratio Gedung X

\begin{tabular}{|c|c|c|c|c|c|c|c|c|c|c|c|c|c|}
\hline Mode & Period & UX & UY & $\mathrm{UZ}$ & SumUX & SumUY & SumUZ & $\mathrm{RX}$ & RY & RZ & SumRX & SumRY & SumRZ \\
\hline 1 & 0,9806 & 81,822 & 0,0102 & 0 & 81,822 & 0,0102 & 0 & 0,0129 & 98,5263 & 0,886 & 0,0129 & 98,5263 & 0,886 \\
\hline 2 & \begin{tabular}{|l|}
0,91789 \\
\end{tabular} & 0,0521 & 72,2269 & 0 & 81,8741 & 72,2371 & 0 & 86,3578 & 0,0673 & 11,1728 & 86,3707 & 98,5936 & 12,0589 \\
\hline 3 & 0,88468 & 0,7712 & 11,0686 & 0 & 82,6453 & 83,3057 & 0 & 13,147 & 0,9473 & 70,9001 & 99,5177 & 99,5408 & 82,9589 \\
\hline 4 & 0,29907 & 11,0389 & 0,0026 & 0 & 93,6842 & 83,3084 & 0 & 0,0005 & 0,0698 & 0,2797 & 99,5182 & 99,6106 & 83,2386 \\
\hline 5 & 0,28415 & 0,06 & 10,0165 & 0 & 93,7442 & 93,3249 & 0 & 0,1072 & 0 & 1,0138 & 99,6254 & 99,6106 & 84,2524 \\
\hline 6 & \begin{tabular}{|l|}
0,27055 \\
\end{tabular} & 0,266 & 1,1212 & 0 & 94,0102 & 94,446 & 0 & 0,0076 & 0,0004 & 9,9724 & 99,633 & 99,611 & 94,2248 \\
\hline 7 & 0,16241 & 3,9626 & 0,0754 & 0 & 97,9728 & 94,5215 & 0 & 0,0071 & 0,3398 & 0,3446 & 99,6401 & 99,9508 & 94,5695 \\
\hline 8 & 0,15707 & 0,1974 & 3,7543 & 0 & 98,1702 & 98,2758 & 0 & 0,3275 & 0,0161 & 0,2014 & 99,9675 & 99,9669 & 94,7708 \\
\hline 9 & \begin{tabular}{|l|}
0,14761 \\
\end{tabular} & 0,2921 & 0,3231 & 0 & 98,4623 & 98,5989 & 0 & 0,0278 & 0,0244 & 3,7657 & 99,9953 & 99,9913 & 98,5365 \\
\hline 10 & 0,11407 & 1,0326 & 0,1928 & 0 & 99,4949 & 98,7917 & 0 & 0,0005 & 0,0055 & 0,2508 & 99,9958 & 99,9967 & 98,7873 \\
\hline 11 & 0,11149 & 0,3049 & 1,1169 & 0 & 99,7999 & 99,9086 & 0 & 0,0037 & 0,0019 & 0,0092 & 99,9996 & 99,9986 & 98,7965 \\
\hline 12 & 0,10372 & 0,1999 & 0,0913 & 0 & 99,9998 & 100 & 0 & 0,0004 & 0,0014 & 1,2034 & 100 & 100 & 100 \\
\hline
\end{tabular}

Berdasarkan hasil participating mass ratio pada gedung $\mathrm{X}$ yang ditunjukkan Tabel 4.1 diperoleh untuk translasi arah sumbu-x adalah 99,998\%, translasi arah sumbu-y adalah $100 \%$ dan rotasi arah sumbu-z adalah 100\%. Dalam hal ini menunjukkan bahwa struktur bangunan publik 5 lantai (gedung X) telah mencapai nilai partisipasi massa ragam 90\% dimana nilai paling sedikit untuk partisipasi massa ragam.

\subsubsection{Mode Shape}

Shape merupakan arah pergerakan bangunan ketika terjadi beban gempa. Arah pergerakan meliputi translasi arah $\mathrm{x}$, translasi arah $\mathrm{y}$, dan rotasi arah $\mathrm{Z}$, dimana syarat ragam gerak pada mode 1 dan 2 mengalami translasi. Ragam gerak struktur bangunan publik 5 lantai (gedung X) dapat dilihat pada Tabel 4.2.

\section{Tabel 4.2 Ragam Gerak Struktur Bangunan Gedung X}

\begin{tabular}{|c|c|c|c|c|}
\hline Mode & Period & UX & UY & RZ \\
\hline 1 & 0,9806 & 81,822 & 0,0102 & 0,886 \\
\hline 2 & 0,91789 & 0,0521 & 72,2269 & 11,1728 \\
\hline 3 & 0,88468 & 0,7712 & 11,0686 & 70,9001 \\
\hline 4 & 0,29907 & 11,0389 & 0,0026 & 0,2797 \\
\hline 5 & 0,28415 & 0,06 & 10,0165 & 1,0138 \\
\hline 6 & 0,27055 & 0,266 & 1,1212 & 9,9724 \\
\hline 7 & 0,16241 & 3,9626 & 0,0754 & 0,3446 \\
\hline 8 & 0,15707 & 0,1974 & 3,7543 & 0,2014 \\
\hline 9 & 0,14761 & 0,2921 & 0,3231 & 3,7657 \\
\hline 10 & 0,11407 & 1,0326 & 0,1928 & 0,2508 \\
\hline 11 & 0,1149 & 0,3049 & 1,1169 & 0,0092 \\
\hline 12 & 0,10372 & 0,1999 & 0,0913 & 1,2034 \\
\hline
\end{tabular}

Berdasarkan Tabel 4.2, nilai partisipasi massa mode 1 lebih dominan arah-x translasi $(81,822 \%)$ dan pada mode 2 lebih dominan arah-y translasi $(72,226 \%)$ 
dan pada mode-3 lebih dominan terhadap arah-z rotasi (70,9001\%). Pada massa mode 1 dan mode 2 dominan translasi karena nilai partisipasi massa menunjukkan nilai yang lebih besar pada mode 1 untuk arah-x dan nilai yang besar pada mode 2 untuk arah-y dan pada mode 3 menunjukkan nilai yang lebih besar untuk arah-z rotasi.

\subsubsection{Kontrol Nilai Akhir Respon Spektrum (Gaya Geser)}

Berdasarkan SNI 1726:2012 Pasal 7.9.4, nilai akhir $V_{\text {dinamik }}$ harus lebih besar sama dengan $85 \% V_{\text {statik, dimana persyaratan tersebut ditunjukkan pada }}$ Gambar 4.1 dan Gambar 4.2.

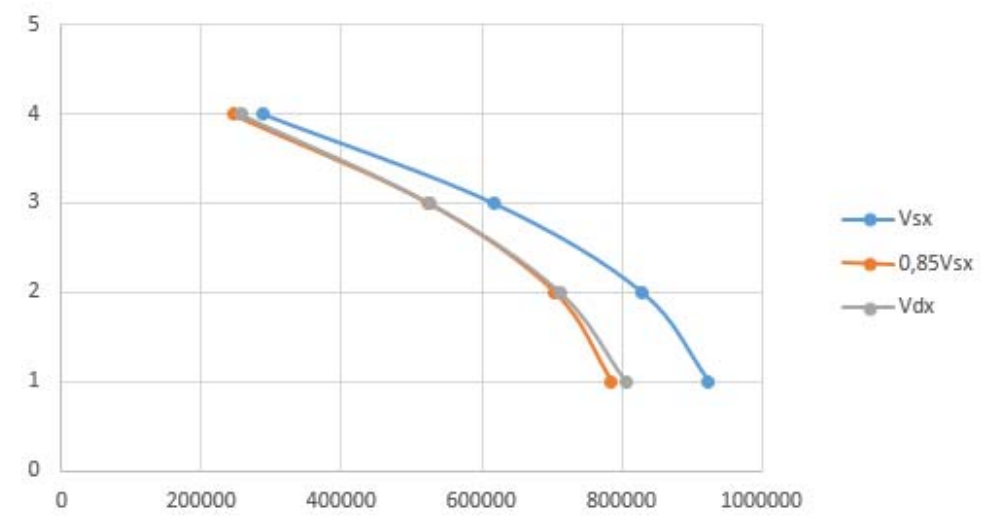

Gambar 4.1 Persyaratan 0,85 $V s_{x} \leq V d_{x}(\operatorname{Arah} X)$

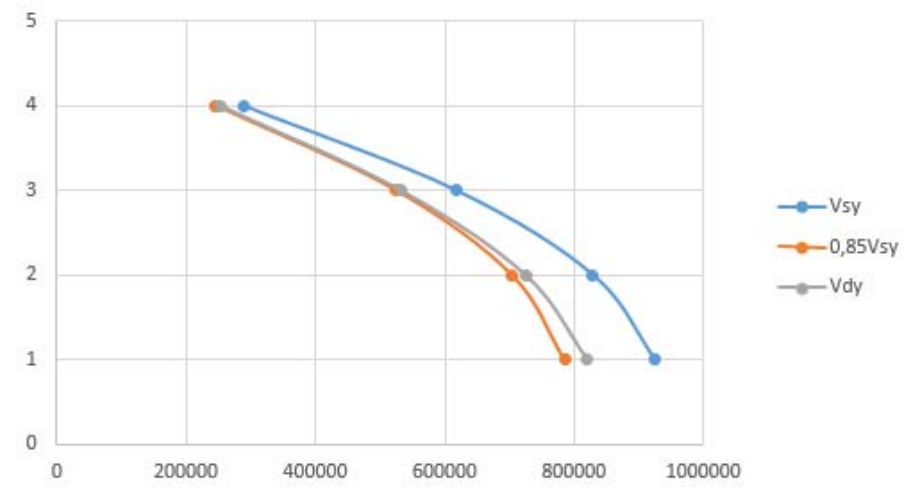

Gambar 4.2 Persyaratan 0,85 $V s_{x} \leq V d_{x}(\operatorname{Arah} Y)$

Persyaratan nilai gaya geser dinamik harus lebih besar daripada $0,85 \%$ gaya geser statik, berdasarkan Gambar 4.1 dan Gambar 4.2, persyaratan nilai gaya geser terpenuhi baik dari lantai 1 sampai dengan lantai 4 bangunan publik 5 
lantai (gedung X) tersebut, akan tetapi perlu adanya faktor perbesaran skala.

Faktor perbesaran skala ditunjukkan pada Tabel 4.3.

Tabel 4.3 Faktor Skala

\begin{tabular}{|c|c|c|c|}
\hline \multirow{2}{*}{ Faktor Skala Awal } & Faktor Perbesaran Skala & \multirow{2}{*}{$\begin{array}{c}\text { Faktor Skala } \\
\text { Setelah Perbesaran }\end{array}$} \\
\cline { 3 - 3 } & 1,226 & $\left(0,85 V_{s} / V_{d}\right)$ & 1,785 \\
\hline$V_{d x}$ & 1,226 & 1,45 & 1,69 \\
\hline$V_{d y}$ & 1,36 & \\
\hline
\end{tabular}

\subsubsection{Simpangan Antar Lantai Gedung}

Simpangan antar lantai $(\Delta)$ struktur gedung ditentukan oleh simpangan antar tingkat akibat pengaruh gempa rencana. Simpangan antar tingkat dihitung dari simpangan struktur gedung akibat pengaruh gempa nominal yang sudah dikali faktor skala. Simpangan antar lantai izin yang diizinkan seperti yang ditunjukkan dengan Persamaan 2.32.

$$
\begin{array}{ll}
\delta & =\delta e \times C_{d} / I_{e} \\
\Delta a & =0,02 h_{s x} \\
C_{d} & =5,5 \text { (faktor pembesaran defleksi) } \\
I_{e} & =1,0 \text { faktor keutamaan gempa }
\end{array}
$$

\begin{tabular}{|c|c|c|c|c|c|c|}
\hline \multirow{2}{*}{ Lantai } & \multirow{2}{*}{$\begin{array}{c}\mathrm{hi} \\
\mathrm{mm}\end{array}$} & \multirow{2}{*}{$\begin{array}{c}\text { Simpangan arah X } \\
\mathrm{mm}\end{array}$} & \multirow{2}{*}{$\begin{array}{c}\text { Simpangan antar } \\
\text { tingkat arah x } \\
\mathrm{mm}\end{array}$} & \multicolumn{3}{|c|}{ Arah X } \\
\hline & & & & $\begin{array}{l}\delta x \\
\mathrm{~mm}\end{array}$ & $\begin{array}{c}\Delta \mathrm{ijin} \\
\mathrm{mm}\end{array}$ & Keterangan \\
\hline Lantai Atap & 14000 & 210,9038 & 32,5331 & 178,93205 & 53,84615385 & Tidak Memenuhi \\
\hline Lantai 4 & 10500 & 178,3707 & 58,088 & 319,484 & 53,84615385 & Tidak Memenuhi \\
\hline Lantai 3 & 7000 & 120,2827 & 72,4889 & 398,68895 & 53,84615385 & Tidak Memenuhi \\
\hline Lantai 2 & 3500 & 47,7938 & 47,7938 & 262,8659 & 53,84615385 & Tidak Memenuhi \\
\hline
\end{tabular}

Hasil simpangan ijin pada bangunan publik 5 lantai (gedung X) dapat dilihat pada Tabel 4.4 dan Tabel 4.5.

\begin{tabular}{|c|c|c|c|c|c|c|}
\hline \multirow{2}{*}{ Lantai } & \multirow{2}{*}{$\begin{array}{l}\mathrm{hi} \\
\mathrm{mm}\end{array}$} & \multirow{2}{*}{$\begin{array}{c}\text { Simpangan arah Y } \\
\mathrm{mm}\end{array}$} & \multirow{2}{*}{$\begin{array}{c}\text { Simpangan antar } \\
\text { tingkat arah y } \\
\mathrm{mm}\end{array}$} & \multicolumn{3}{|c|}{ Arah Y } \\
\hline & & & & $\begin{array}{l}\delta x \\
\mathrm{~mm}\end{array}$ & $\begin{array}{c}\Delta \text { ijin } \\
\mathrm{mm}\end{array}$ & Keterangan \\
\hline Lantai Atap & 14000 & 185,923 & 27,9026 & 153,4643 & 53,84615385 & Tidak Memenuh \\
\hline Lantai 4 & 10500 & 158,0204 & 50,2104 & 276,1572 & 53,84615385 & Tidak Memenuh \\
\hline Lantai 3 & 7000 & 107,81 & 63,9057 & 351,48135 & 53,84615385 & Tidak Memenuh \\
\hline Lantai 2 & 3500 & 43,9043 & 43,9043 & 241,47365 & 53,84615385 & Tidak Memenuh \\
\hline
\end{tabular}

Tabel 4.4 Kontrol Simpangan Arah-X

Tabel 4.5 Kontrol Simpangan Arah-Y 
Berdasarkan Tabel 4.4 dan 4.5 menunjukkan bahwa hasil simpangan untuk arah-x dan arah-y tidak memenuhi simpangan ijin yang telah ditentukan SNI 1726:2012. Hasil simpangan yang terjadi pada bangunan publik 5 lantai (gedung $\mathrm{X}$ ) terjadi kenaikan nilai simpangan pada lantai 3 dan menurun kembali pada lantai 4 dan begitu juga pada atap dikarenakan adanya penambahan massa yaitu pada lantai 3 dan 4 yaitu ruang arsip.

\subsection{Analisis Pushover}

\subsubsection{Tingkat Kerusakan}

Tingkat kerusakan struktur paling parah pada bangunan publik 5 lantai (gedung X) pada PUSH 2 ini ditunjukkan pada step 4 yang terdapat pada beberapa balok seperti pada Gambar 4.3. Kategori paling parah dimana balok terjadinya degradasi kekuatan struktur yang besar, sehingga kondisi struktur tidak stabil dan collapse kemudian hingga struktur tidak mampu menahan gaya geser dan hancur

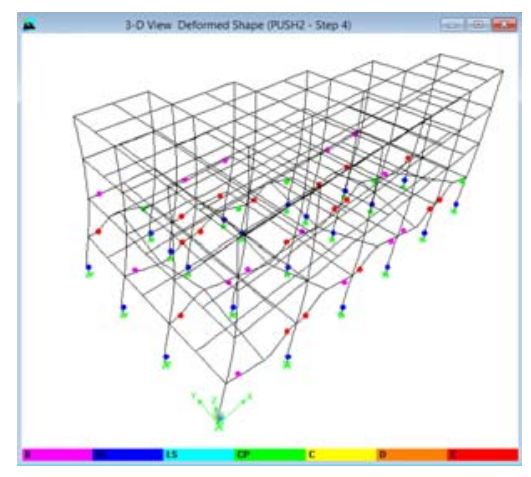

\section{Gambar 4.3 Tingkat Kerusakan Struktur Gedung X pada PUSH 2 Step 4}

Tingkat kerusakan struktur paling parah pada bangunan publik 5 lantai (gedung X) pada PUSH 2 terus meningkat pada balok lantai 2 seperti pada Gambar 4.4. Kategori paling parah yang ditunjukkan bahwa terjadinya degradasi kekuatan struktur yang besar, sehingga kondisi struktur tidak stabil dan collapse kemudian hingga struktur tidak mampu menahan gaya geser dan hancur. 


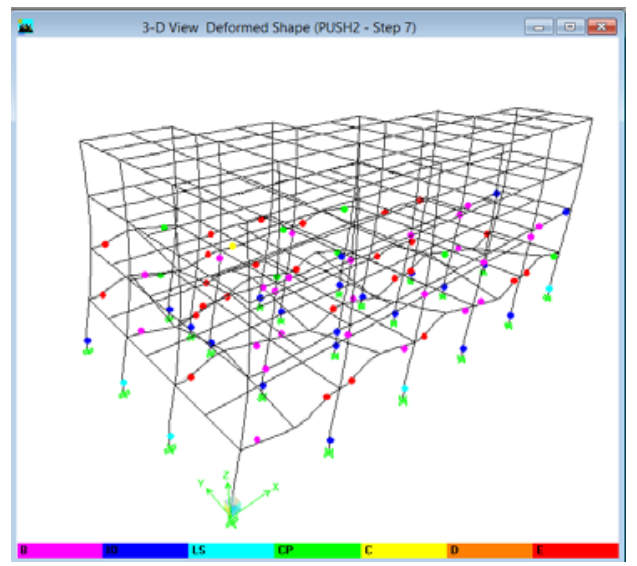

\section{$\begin{array}{llllll}\text { Gambar } & \text { 4.4 Tingkat } & \text { Kerusakan } & \text { Struktur Gedung } \mathrm{X}\end{array}$ pada PUSH 2 Step 7}

Tingkat kerusakan paling parah selanjutnya ditinjau pada kasus 3 yaitu pada PUSH 3. Pada PUSH 3 menunjukkan tingkat kerusakan paling parah ditunjukkan pada step 1 seperti pada Gambar 4.5 dimana tingkat kerusakan pertama terjadi pada balok lantai 2 dan 3 dengan tingkat kerusakan dimana terjadinya degradasi kekuatan struktur yang besar, sehingga kondisi struktur tidak stabil dan hampir collapse.

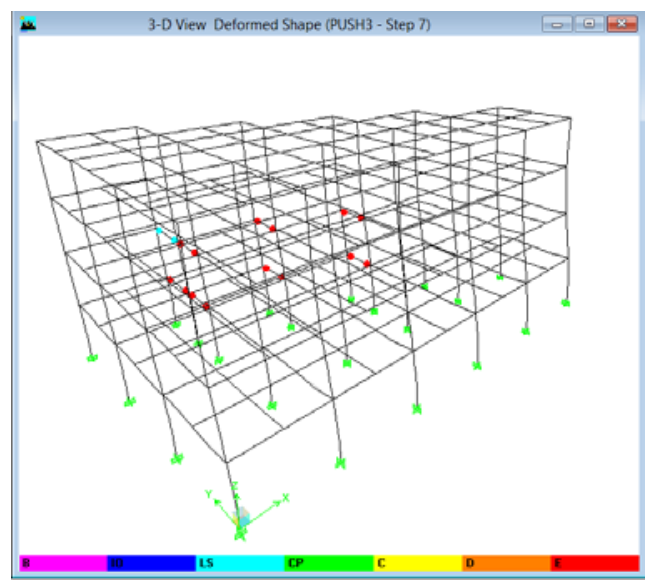

Gambar 4.5 Tingkat Kerusakan Struktur Gedung X pada PUSH 3 Step 7

Tingkat kerusakan pada kasus 3 (PUSH 3) menunjukkan tingkat kerusakan paling parah ditunjukkan pada step 1 seperti pada Gambar 4.6 dimana tingkat kerusakan pertama terjadi pada balok lantai 2 dan 3 dengan tingkat kerusakan 
yang menunjukkan terjadinya degradasi kekuatan struktur yang besar, sehingga kondisi struktur tidak stabil dan hampir collapse.

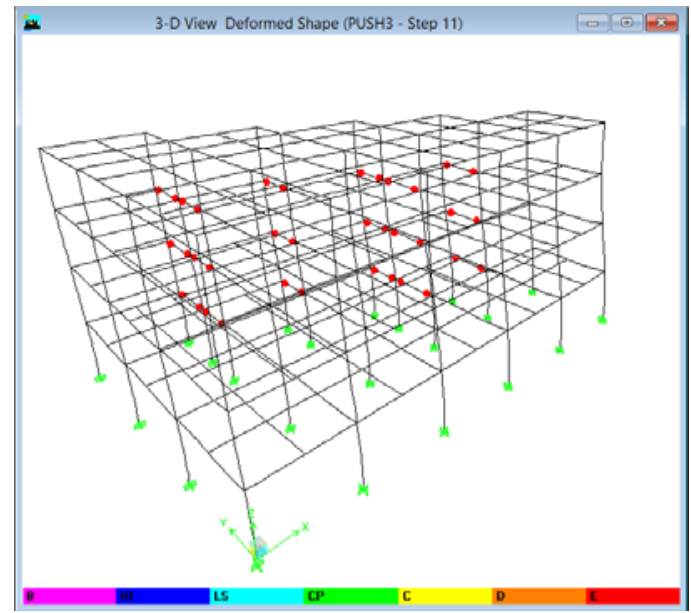

\section{Gambar 4.6 Tingkat Kerusakan Struktur Gedung X pada PUSH 3 Step}

11

Tingkat kinerja struktur pada step 12 ditunjukkan pada kolom 3-A, 5-A dan 6-A seperti pada Gambar 4.7. Tingkat kerusakan menunjukkan bahwa struktur menunjukkan batas linear yang kemudian diikuti terjadinya pelelehan pertama pada struktur.

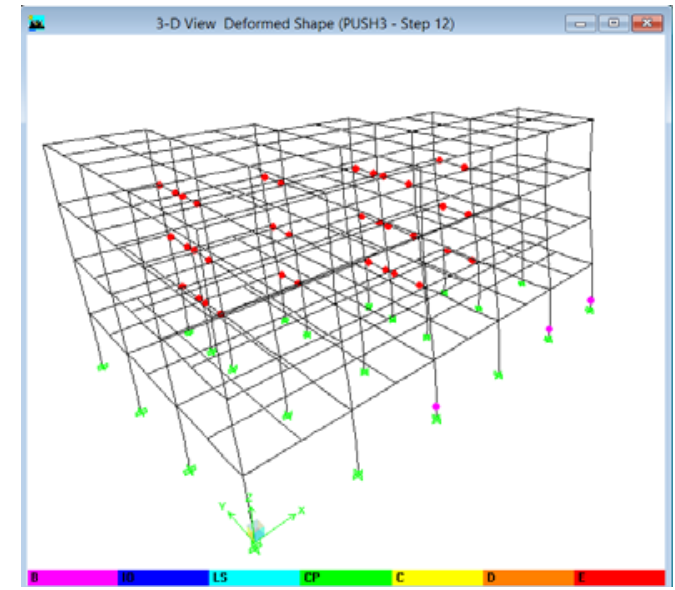

Gambar 4.7 Tingkat Kerusakan Struktur Gedung X pada PUSH 3 Step 12. 


\subsection{Pembahasan}

Tujuan dari penelitian ini adalah menganalisis kelayakan struktur bangunan dengan meninjau simpangan berdasarkan hasil analisis dinamik respon spektrum dan meninjau tingkat kerusakan berdasarkan hasil analisis pushover. Investigasi awal yang telah dilakukan menunjukkan bahwa terjadinya retak pada elemen struktural pelat dan balok lantai 4 . Retak yang terjadi pada pelat dan balok pada lantai 4 merupakan retak non-struktural. Informasi yang didapat dari investigasi dan wawancara yang telah dilakukan memberi tahu bahwa pada lantai 3 dan lantai 4 adalah ruang arsip, dimana berkas arsip setiap tahun masuk dan menambah beban arsip pada lantai 3 dan lantai 4 .

Data hasil pengujian core drill yang diperoleh menunjukkan bahwa nilai mutu beton untuk elemen struktur balok dan kolom tidak memenuhi persayaratan standar mutu beton untuk bangunan gempa. Kualitas beton yang rendah pada elemen struktur kolom dan balok kemungkinan terjadinya penurunan kualitas beton.

Hasil analisis respon dinamik menunjukkan bahwa hasil simpangan untuk arah-x dan arah-y tidak memenuhi persyaratan yang ditentukan SNI 1726-2012. Hasil simpangan yang menunjukkan bahwa pada lantai 4 dan lantai atap terjadi perubahan nilai yang mengecil dikarenakan penambahan beban hidup pada lantai 3 dan lantai 4. Simpangan besar dan tidak memenuhi persyaratan simpangan ijin yang telah ditentukan SNI 1726-2012 menunjukkan bahwa kekakuan gedung masih kurang menahan beban gempa yang terjadi.

Hasil analisis pushover juga menunjukkan bahwa pelelehan sendi plastis pertama terjadi pada ujung kolom perletakan yang disebabkan karena perubahan kolom yang terjepit menjadi sendi. Mekanisme keruntuhan yang terjadi pada bangunan publik 5 lantai (gedung $\mathrm{x}$ ) adalah beam sidesway mechanism. Mekanisme keruntuhan beam sidesway mechanism adalah mekanisme yang diharapkan dikarenakan pelelehan sendi plastis hanya terjadi pada ujung-ujung balok dan ujung perletakan kolom. 


\section{SIMPULAN DAN SARAN}

\subsection{Simpulan}

Berdasarkan analisis yang telah dilakukan sebelumnya, maka diperoleh simpulan sebagai berikut:

1. Hasil observasi lapangan menunjukkan terjadinya retak pada elemen struktur seperti pada pelat dan balok lantai 4 .

2. Hasil simpangan antar tingkat bangunan publik 5 lantai (gedung $\mathrm{X}$ ) pada arah-x dan arah-y tidak memenuhi persyaratan dari simpangan izin yang telah ditetapkan SNI 1726-2012.

3. Hasil kelayakan struktur bangunan publik 5 lantai (gedung X) berdasarkan hasil pengamatan visual (observasi), hasil uji bahan, pemodelan, analisis yang telah dilakukan menunjukkan bahwa struktur disimpulkan tidak aman untuk menahan gaya gempa dimana beberapa persyaratan SNI tidak memenuhi, sehingga struktur bangunan publik 5 lantai (gedung X) diperlukan perkuatan pada elemen struktur yang lemah.

\subsection{Saran}

Saran untuk penelitian lebih lanjut adalah:

1. Meninjau kembali gambar perencanaan (as built drawing) dan disesuaikan dengan hasil pengujian, agar yang hasil pemodelan struktur yang ditinjau sesuai dengan hasil perencanaan awal.

2. Dilakukan penelitian lebih lanjut agar dapat menanggulangi kerusakan yang terjadi dan memberikan pilihan yang tepat untuk perkuatan struktur untuk mengatasi terjadinya kehancuran pada gedung.

\section{DAFTAR PUSTAKA}

1. ACI 318-02/IBC2003, Concrete Frame Design Manual For ETABS. California, USA.

2. Applied Technology Council (ATC-40), 1996, Seismic Evaluation and Retrofit of Concrete Buildings, California, USA. 
3. ASCE, 2000, FEMA 356 "Prestandard and Commentary for the Seismic Rehabilitation of Buildings," Federal Emergency Management Agency, Washington, D.C.

4. Badan Standarisasi Nasional, 2013, Persyaratan Beton Struktural untuk Bangunan Gedung (SNI 2847:2013), BSN, Jakarta.

5. Badan Standarisasi Nasional, 2012, Tata Cara Perencanaan Ketahanan Gempa untuk Struktur Bangunan Gedung dan Non Gedung (SNI 1726:2012), BSN, Jakarta.

6. BNPB, 2015, Badan Nasional Penanggulangan Bencana (BNPB).

7. Chopra, A.K., 1995, Dynamics of Structures (Theory and Applications to Earthquake Engineering).

8. Dewobroto, W. (2005). Jurnal Teknik Sipil. Evaluasi Kinerja Struktur Baja Tahan Gempa dengan Analisa Pushover.

9. Dewobroto, W., 2007, Aplikasi Rekayasa Konstruksi

10. Dewobroto, W., 2009, Foto Foto Gempa di Padang Retrieved 7 Agustus, 2016, from https://wiryanto.net/2009/10/26/foto-foto-gempa-di-padang/

11. Douglas, K.T., The Development of A Reinforced Concrete Plastic Hinge Model.

12. Irsyam, M., 2010, Ringkasan Hasil Studi Tim Revisi Peta Gempa 2010.

13. KBBI, 2015, Kamus Besar Bahasa Indonesia (KBBI).

14. Kompas, 2009, 17 Orang Meninggal Akibat Gempa Padang. Retrieved 7 Agustus,2016,from http://regional.kompas.com/read/2009/10/15/1023516/1.117.orang.mening gal.akibat.gempa.padang

15. Nawy, E.G., 1985, Beton Bertulang, diterjemahkan oleh Bambang Suryoatmono, PT. ERESCO.

16. Nobel, A., 2016, Retrieved from http://blog.nobelconsultant.com/jenisjenis-pengujian-beton-untuk-analisa-kelayakan-struktur-bangunan/

17. P. Anindityo Budi, 2011. Evaluasi Kinerja Seismik Stuktur Beton dengan Analisis Pushover Prosedur A Menggunakan Program ETABS v 9.50. Skripsi Program Studi Teknik Sipil Universitas Sebelas Maret, Surakarta. 
18. Park, R., dkk, 1975, Reinforced Concrete Structure, United States of $\underline{\text { America }}$

19. Pranata, Y.A., 2006, Evaluasi Kinerja Gedung Beton Bertulang Tahan Gempa dengan Pushover Analysis (Sesuai ATC-40, FEMA 356, dan FEMA 440).

20. Purnomo E., dkk., 2014, Analisa Kinerja Struktur Pada Gedung Bertingkat dengan Analisis Dinamik Respon Spektrum Menggunakan Software ETABS.

21. Sinaga, R., 2016, Kajian Evaluasi Kinerja Bangunan Terhadap Siaga Bencana Gempa, Universitas Kristen Maranatha.

22. Williams, E.A., 2007, National Association of Broadcasters Engineering. 